\title{
Editorial: Institutional Problems and Responses
}

\section{MiKLÓs KÖNCZÖL - ViKTOR OLIVÉR LÖRINCZ - GÁBOR KeCSKÉS*}

Although not edited as a thematic collection, the first issue of our 2019 volume is remarkably coherent in terms of the problems tackled by our authors, all of them being related to specific institutions. In an age where a series of crises, socio-cultural as well as economic, test the flexibility and durability of democratic institutions, these surveys into the challenges and promises of institutional solutions could not be more à propos.

In the first article, Bachynskyy and Radeiko review blockchain and cryptocurrency regulations in Ukraine. Their perspective is twofold: on the one hand, they give an overview of problems arising in Ukrainian legal practice in connection with the use of blockchain technology; on the other hand, they argue for a more open-minded approach when legislating on new information technologies. Here, their contention is that since the state cannot (and should not) impede technical development, it should adopt a less restrictive stance to be able to profit from its outcomes.

Izarova, Szolc-Nartowski and Kovtun likewise focus on Ukrainian law, but what they examine is a specifically legal institution with roots as far as ancient Rome: the amicus curiae. In addition to the historical survey, they also include an Easter European comparison, to provide ample backing for their claim that - in contrast to what we have seen in terms of blockchain regulation - Ukrainian procedural law is on the progressive side, and may serve as a model for other legislations in the region. In that sense, the article adds to the considerations formulated by Alan Uzelac in one of the previous issues of this Journal. ${ }^{1}$

Kleczkowska's article adopts a somewhat different approach, starting from the international perspective, and using a domestic (in that case, Polish) example to show that countries not yet afflicted by serious terrorist acts may also have to deal with cases involving terrorist crimes. Their task, she argues, would be facilitated by "a comprehensive legal instrument and an international organ with jurisdiction over the crime of terrorism".

In a similar vein, Pap and Śledzińska-Simon look for possible supra-national institutional responses for the challenge posed by the illiberal turn in EU member states such as Hungary and Poland. ${ }^{2}$ Yet here, it is not the absence of such institutions but their weakness that is considered problematic by the authors, who point out that the breach of community norms may go beyond a purely legal problem, and raises a threat to mutual trust between the member states. ${ }^{3}$ Analysing multi-level constitutionalism, they conclude that legal institutional solutions may be insufficient in themselves, but also that they can foster political reaction (eg. by mandatory voting).

* Managing editors of Hungarian Journal of Legal Studies - Acta Juridica Hungarica, Research Fellow, Junior Research Fellow and Research Fellow of the Centre for Social Sciences, Institute for Legal Studies, Hungarian Academy of Sciences Centre of Excellence.

1 Cf. Uzelac (2017).

2 On the illiberal turn in Hungary, see Pap (2018).

${ }^{3}$ Notwithstanding the fact that 'liberal norms' may be questionable sometimes, e.g. in terms of minority representation and participation: see Agarin (2017). 
Saktorová, too, examines an institution that is pre-legal but raises serious problems for regulation: that of "private life". Moreover, she also argues for the insufficiency of legal means for the protection of one's privacy. Even though there is a number of international and domestic constitutional safeguards, making use of these - often against a similar multitude of control and surveillance mechanisms originally meant to provide protection against other, more readily perceptible threats - requires a personal decision on the part of the individual.

Wiszowaty looks at the historical development of the Polish constitutional system, with a special focus on the question of checks and balances. This article brings some important insights to the discussion on post-2008 constitutional changes in the region, initiated in our Journal by the recent collection of articles by Iván Halász as guest editor $(58 / 2)$. At the same time, it broadens the perspective, especially through its comparisons from the period of the Polish-Lithuanian Commonwealth.

In the final contribution to the present issue, Pödör reviews a recent book, edited by Mátyás Bencze and Gar Yein $\mathrm{Ng}^{4}$ on the possibility and limits of assessing the quality of legal reasoning. While a good deal of methodological scepticism may be in order in terms of such promises, especially concerning the quantitative methods, ${ }^{5}$ the demand for benchmarks enabling purposive reforms seems constant.

\section{LITERATURE}

Agarin, Timofey, 'Nation-States into Nationalising States: The Impact of Transformation on Minority Participation in the Baltic States' (2017) 3/4 Intersections. East European Journal of Society and Politics 41-65.

Bencze, Mátyás, Ng, Gar Yein (eds), How to Measure the Quality of Judicial Reasoning (Springer, 2018).

Jakab, András and Lörincz, Viktor, 'International Indices as Models for the Rule of Law Scoreboard of the European Union: Methodological Issues' (2017) MPIL Research Paper Series No. 2017-21 $<$ https://ssrn.com/abstract=3032501> accessed 20 September 2019.

Pap, András L., Democratic Decline in Hungary: Law and Society in an Illiberal Democracy (Routledge, 2018).

Uzelac, Alan, 'Towards European Rules of Civil Procedure: Rethinking Procedural Obligations' (2017) 58/1 Hungarian Journal of Legal Studies 3-18.

4 Bencze and Ng (2018).

5 See, in terms of rule of law indices, Jakab and Lörincz (2017). 